\title{
Which clinical conditions are most suitable for induction of automated peritoneal dialysis?
}

\author{
Masashi Mizuno*, Yasuhiro Suzuki, Fumiko Sakata and Yasuhiko Ito
}

\begin{abstract}
This review article is an invited review by both the Japanese Society for Dialysis Therapy (JSDT) and Japanese Society for Peritoneal Dialysis (JSPD).

Automated peritoneal dialysis (APD) using a cycler machine is an alternative choice for patients who are on peritoneal dialysis (PD) for the treatment of end-stage renal disease (ESRD). The main purpose is to allow more free time and an improved quality of life for PD patients versus continuous ambulatory PD (CAPD). However, it remains unclear which modality is a better choice, especially with regard to the induction period of PD, due to a lack of research. When we propose PD therapy to ESRD patients, in addition to the obvious benefit of more free time, we also need to consider the advantages and disadvantages with regard to each patient's medical comorbidities, physical condition, social activities, psychological readiness, and medical economics. In this review, we attempted to determine which method is more advantageous overall, APD or CAPD. In conclusion, it is important to consider the medical, social, physical, and economic aspects for each PD patient as well as patient preference when helping patients choose between APD and CAPD.
\end{abstract}

Keywords: Peritoneal dialysis, APD, CAPD, Advantages, Disadvantages

\section{Background}

This review article is an invited review by both the Japanese Society for Dialysis Therapy (JSDT) and Japanese Society for Peritoneal Dialysis (JSPD).

Automated peritoneal dialysis (APD) was introduced in the 1960s using concepts that are similar to current methods. To perform peritoneal dialysis (PD) in patients with end-stage renal failure (ESRD), peritoneal puncture was essential for the insertion of a cannula to access the abdominal cavity each time a patient presented for dialysis, until the development of the silicon-based Tenckhoff catheter introduced by Henry Tenckhoff in 1968 [1]. Therefore, peritonitis occurred very frequently and prevented clinical use of continuous long-term PD therapy. Boen et al. reported that APD was performed intermittently with the use of huge amounts of PD fluid (PDF) [2]. To induce APD, large 12-gal (close to $45 \mathrm{~L}$ ) glass bottles of PDF were required for the automatic cycler machine. They described that ESRD patients on APD therapy enjoyed more free time as it allowed for the exchange of larger amounts of fluid over shorter periods of time; thus, dialysis could be performed intermittently (once every 3 or 4 days). Moreover, patients experienced less frequent episodes of peritonitis.

In 1972, Tenckoff et al. proposed a much simpler APD system that was more compact and attached to a reverse osmosis unit to eliminate the need for huge bottles [3], and the Drake-Willock PD cycler machine was developed with a reverse osmosis system [4]. The development of the Tenckhoff catheter allowed permanent access to the peritoneal cavity. Glass bottles for containment of PDF evolved into plastic bags that continue to be used today [5]. Because of the induction of continuous ambulatory PD (CAPD), PD therapy became safer and ESRD patients were completely released from bedrest in the hospital and had greater

* Correspondence: mmizu@med.nagoya-u.ac.jp; masashim1.jp@yahoo.co.jp

Renal Replacement Therapy, Division of Nephrology, Nagoya University

Graduate School of Medicine, Nagoya, Japan

(c) 2016 The Author(s). Open Access This article is distributed under the terms of the Creative Commons Attribution 4.0 International License (http://creativecommons.org/licenses/by/4.0/), which permits unrestricted use, distribution, and reproduction in any medium, provided you give appropriate credit to the original author(s) and the source, provide a link to the Creative Commons license, and indicate if changes were made. The Creative Commons Public Domain Dedication waiver (http://creativecommons.org/publicdomain/zero/1.0/) applies to the data made available in this article, unless otherwise stated. 
freedom. The CAPD system also contributed to a decrease in peritonitis and gastrointestinal injuries caused by repeated puncture with a PD cannula. After that, a system was developed similar to present-day APD. In the 1980s, the automated peritoneal dialysis cycler machine, Pac-X (Baxter Limited, Tokyo, Japan), was introduced worldwide [6] and was also used as a primary cycler for APD in Japan, followed by the Pac-X cycler II (Baxter, Fig. 1a). The Quantum PD dialysis machine (Baxter), a simple automatic bag change system that could perform only one bag change per night, was also used to support nocturnal dialysis regimens in Japan (Fig. 1b). Now, we can choose from four types of much more compact cycler machines from four different PD companies (Fig. 2).

When cycler machine-operated APD was introduced, its greatest advantage was a larger selection of PD treatments options, including continuous cycling PD (CCPD) (Fig. 3), and different types of dialysate solutions could also be mixed in a cycler machine. In the present method of APD, the cycler machine is also advantageous because of the decreased frequency of PDF bag changes needed. Currently, a standardized APD selection does not exist in Japan. Unfortunately, there are a few studies originating in Japan for supporting the use of APD. Therefore, the decision to select induction of APD is often influenced by experiences and preferences of physicians, patients, and/or caregivers. Thus, the question remains, is it better to choose CAPD or APD for patients? In this review, we refer to previous reviews and recent reports and summarize the advantages and disadvantages with regard to medical,

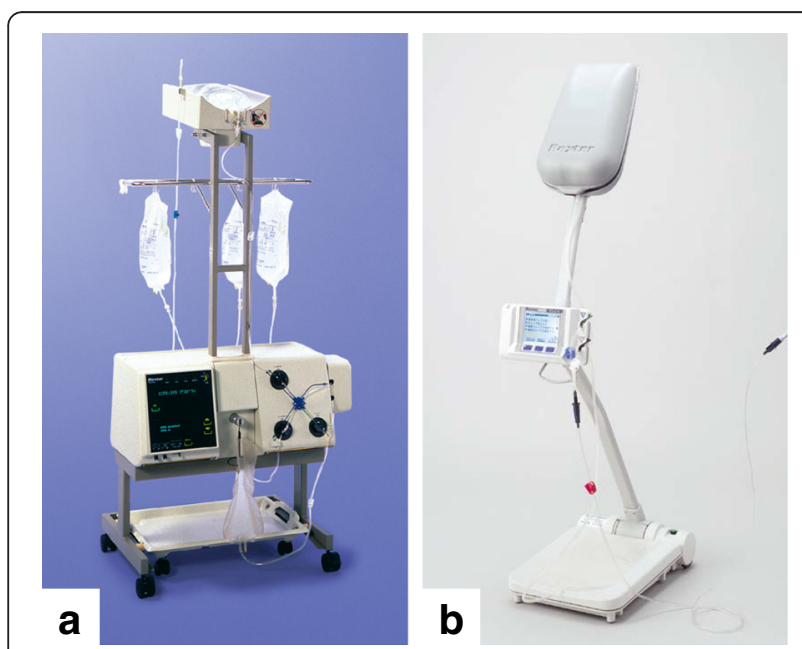

Fig. 1 Earlier-generation machines that have supported automated peritoneal dialysis (APD) in Japan. Before recent models of cyclers, there were several commercially based machines. a Pax-X cycler ॥ and $\mathbf{b}$ Quantum PD dialysis machine. The two types of APD machines were purchased by Baxter Japan and are commonly used in Japan (photo frames courtesy of Baxter Limited (Tokyo, Japan)) socioeconomic, and psychological aspects of care when choosing the best APD system.

\section{Which is more medically advantageous to patients with ESRD: APD or CAPD?}

Prognosis for life survival and/or technical survival

In a recent review article summarizing reports concerning life survival and technical survival before 2011 [7], most showed no significant difference between APD and CAPD, except for a retrospective cohort study that demonstrated APD to be more advantageous [8]. Another report that analyzed long-term survival showed CAPD and APD to be similar [9].

After 2011, it has also been reported that there is no difference in life survival and technical survival between APD and CAPD in Hong Kong in 2013 [10]. In contrast, it was reported that technical survival of APD patients is better than for CAPD patients, even if death was excluded as a reason for technical failure, in the UK in 2011 [11]. In a recently published prospective and large-scale national cohort study in Brazil in 2015, technical survival was not different between APD and CAPD, although life survival was better in APD than CAPD [12].

Of note, an interesting report showed that PD patient survival in those in the high transporter category on the peritoneal equilibration test (PET), which is usually performed as an assessment of peritoneal membrane function in PD patients, was better with APD than with CAPD [13]. This finding might support the assumption that frequent PD bag changes with APD could improve total ultrafiltration in PD patients in the high transporter category on the PET. In contrast, survival in those patients in the low transporter category on the PET was reported to be poorer with APD than with CAPD in that study.

As a brief summary, patient survival and technical survival with regard to PD therapy may be similar between APD and CAPD, although a few reports have shown advantages of APD usage, especially in PD patients in the high transporter category on the PET. Summary is shown in Table 1.

\section{Adequacy of dialysis of creatinine and blood urea nitrogen between APD and CAPD}

Theoretically, adequacy of dialysis of creatinine and blood urea nitrogen (BUN) is dependent on the frequency of bag changes, dwell time, and amount of PDF. Therefore, it is difficult to compare APD and CAPD. When CAPD therapy is considered in patients with a large body mass with ESRD and who have no residual renal function (RRF), five or more bag changes may be required [14]. Therefore, induction of APD is useful to decrease the number of PD bag changes in those patients. On the other hand, in several reports concerned with the 

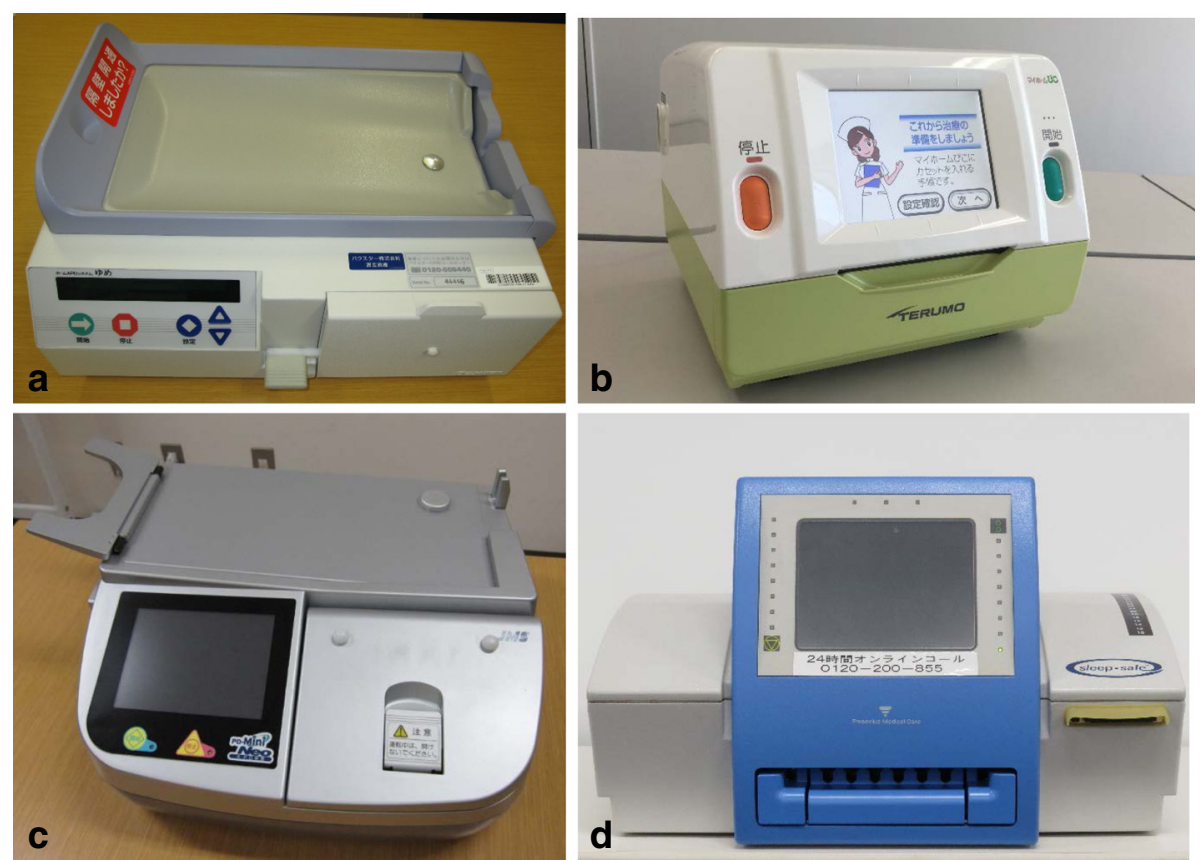

Fig. 2 Recent modern cycler machines for automated peritoneal dialysis delivered from four companies in Japan. In Japan, four companies delivered four different cycler machines, respectively, a the "home APD system YUME," which was purchased by Baxter (Tokyo, Japan), b the "My Home PICO APD ${ }^{\circledR}$ system," which was purchased by TERUMO Co. (Tokyo, Japan), c the "APD system PD-Mini Neo" which was purchased by JMS Co. (Tokyo, Japan), and $\mathbf{d}$ the "Sleepsafe ${ }^{\oplus}$ APD system" which is purchased by Fresenius Medical Care Japan (Tokyo, Japan)

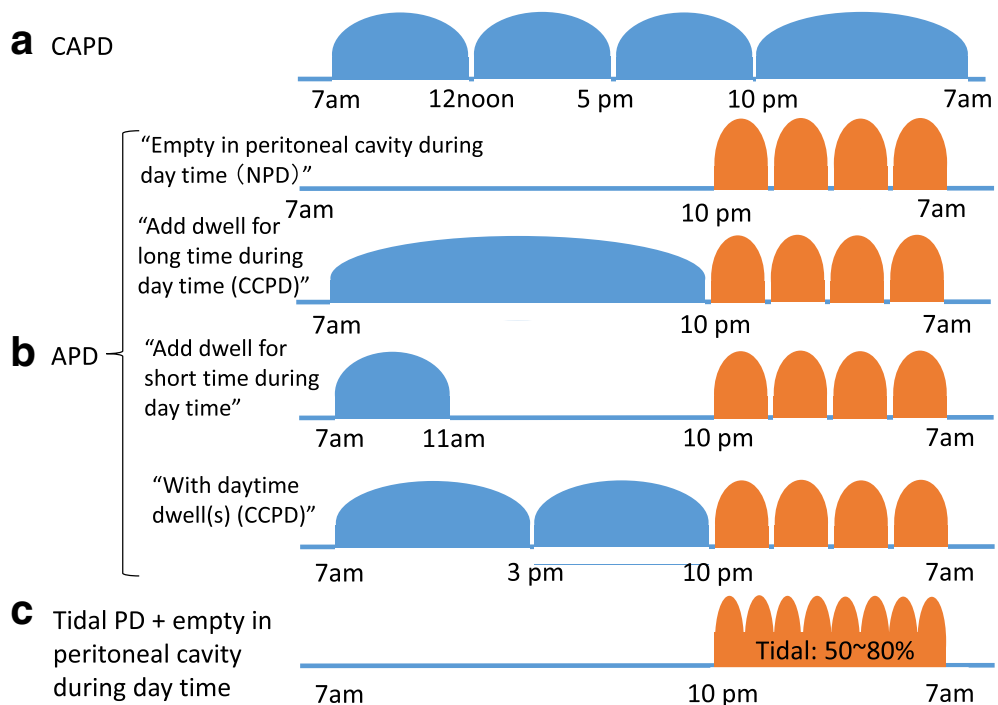

Fig. 3 Various schedules of dwell time in peritoneal dialysis (PD) to help select modalities of PD. Typhical pattern of continuous ambulatory PD is shown in a. We have the ability to select various options for PD menus after induction of automated PD (APD), which are shown in $\mathbf{b}$. Flexibility in the PD menu allows for adjustment to various lifestyles of PD patients in addition to managing the increase in total PD volume for adequacy of dialysis and shortening each dwell time for enough ultrafiltration. As an alternative methods, tidal PD was a choice of PD (c). Solid orange area shows dwells of the cyclers. CCPD continuous cyclic peritoneal dialysis, TAPD tidal automated peritoneal dialysis, NPD nocturnal PD 
Table 1 Studies of comparison between APD and CAPD for life survival and/or technical survival

\begin{tabular}{|c|c|c|c|c|c|c|}
\hline $\begin{array}{l}\text { Study (published year) } \\
\text { [reference] }\end{array}$ & Study design & Setting countries & Data source & $\mathrm{N}(\mathrm{CAPD}, \mathrm{APD})$ & Duration of observation & Results \\
\hline $\begin{array}{l}\text { de Fijter CW et al. (1994) } \\
\text { [15] }\end{array}$ & $\begin{array}{l}\text { Prospective } \\
\text { randomized study }\end{array}$ & Netherland 1988-1991) & Single center & $82(41,41)$ & 24 months & Ns. \\
\hline $\begin{array}{l}\text { Guo A et al. (2003) } \\
\text { [85] }\end{array}$ & $\begin{array}{l}\text { Retrospective } \\
\text { cohort study }\end{array}$ & USA $(1999,2000,2001)$ & Multicenter & $>30000(\mathrm{~N} / \mathrm{A})$ & N/A & $\begin{array}{l}\text { APD is better within } \\
1 \text { year after PD induction }\end{array}$ \\
\hline $\begin{array}{l}\text { Badve SV et al. (2008) } \\
\text { [86] }\end{array}$ & National registry & $\begin{array}{l}\text { Australia, New Zealand } \\
(1999-2004)\end{array}$ & $\begin{array}{l}\text { Multicenter } \\
\text { (ANZDATA) }\end{array}$ & $4128(2393,1735)$ & 5 years & Ns. \\
\hline $\begin{array}{l}\text { Liao CT et al. (2008) } \\
\text { [87] }\end{array}$ & $\begin{array}{l}\text { Retrospective } \\
\text { observational study }\end{array}$ & Taiwan (1996-2005) & Single center & $270(188,82)$ & 6 months & Ns. \\
\hline $\begin{array}{l}\text { Sanchez et al. (2008) } \\
\text { [8] }\end{array}$ & $\begin{array}{l}\text { Retrospective } \\
\text { cohort study }\end{array}$ & Mexico (2003-2005) & Single center & $237(139,98)$ & 2 years & APD is better \\
\hline $\begin{array}{l}\text { Mehrota R et al. (2009) } \\
\text { [88] }\end{array}$ & National registry & USA (1996-2004) & $\begin{array}{l}\text { Multicenter } \\
\text { (USRDS) }\end{array}$ & $66381(42942,23439)$ & $2 \sim 10$ years & Ns. \\
\hline $\begin{array}{l}\text { Michels WM, et al. (2009) } \\
\text { [89] }\end{array}$ & $\begin{array}{l}\text { Retrospective } \\
\text { cohort study }\end{array}$ & $\begin{array}{l}\text { Netherland } \\
(1997-2006)\end{array}$ & $\begin{array}{l}\text { Multicenter } \\
\text { (NECOSAD) }\end{array}$ & $649(562,87)$ & 5 years & Ns. \\
\hline $\begin{array}{l}\text { Johnson DW et al. (2010) } \\
\text { [13] }\end{array}$ & National registry & Australia, New Zealand & $\begin{array}{l}\text { Multicenter } \\
\text { (ANZDATA) }\end{array}$ & $\begin{array}{l}628(486,142) \\
\text { in H category }\end{array}$ & 3 months to 10 years & $\begin{array}{l}\text { Ns. Fatal risk was } \\
\text { decreased in } \mathrm{H} \text { Category }\end{array}$ \\
\hline $\begin{array}{l}\text { Balasubramanian G et al. } \\
\text { (2011) [11] }\end{array}$ & $\begin{array}{l}\text { Retrospective } \\
\text { observational study }\end{array}$ & UK (2003-2008) & Single center & $372(178,194)$ & 5 years & $\begin{array}{l}\text { APD was better } \\
\text { for survival }\end{array}$ \\
\hline $\begin{array}{l}\text { Conssen TT et al. (2011) } \\
\text { [90] }\end{array}$ & $\begin{array}{l}\text { Retrospective } \\
\text { observational study }\end{array}$ & USA (2001-2008) & Multicenter & $620(179,441)$ & 3 month-7 years & APD was better \\
\hline $\begin{array}{l}\text { Sun CY et al. (2010) } \\
\text { [91] }\end{array}$ & $\begin{array}{l}\text { Retrospective } \\
\text { observational study }\end{array}$ & Taiwan (1997-2008) & Single center & $282(121,161)$ & 3 months -10 years & APD was better \\
\hline $\begin{array}{l}\text { Kwan BC et al. (2013) } \\
\text { [10] }\end{array}$ & $\begin{array}{l}\text { Retrospective } \\
\text { observational study }\end{array}$ & $\begin{array}{l}\text { Hong Kong } \\
(1995-2011)\end{array}$ & Multicenter & $270(180,90)$ & 9.5 months -46.5 months & Ns. \\
\hline $\begin{array}{l}\text { Beduschi GC et al. (2015) } \\
\text { [12] }\end{array}$ & $\begin{array}{l}\text { Prospective } \\
\text { cohort study }\end{array}$ & Brazil (2004-2011) & Multicenter & $2890(1445,1445)$ & 5 years & $\begin{array}{l}\text { Life survival of APD was } \\
\text { better than that of CAPD. } \\
\text { Ns. for technical survival }\end{array}$ \\
\hline $\begin{array}{l}\text { Mizuno M et al. (2016) } \\
\text { [35] }\end{array}$ & $\begin{array}{l}\text { Retrospective } \\
\text { cohort study }\end{array}$ & Japan (2010-2012) & Multicenter & $200(119,81)$ & 3 years & Ns. \\
\hline
\end{tabular}

Ref. Bieber SD et al. [7]

Ns. significant differences between CAPD and CAD, N/A not available in the text, ANZDATA Australia and New Zealand Dialysis and Transplant, NECOSAD Netherlands Cooperative Study on the Adequacy of Dialysis, USRDA US Renal Data System 
comparison of the adequacy of dialysis between APD and CAPD $[15,16]$, no significant difference was reported.

\section{Removal of sodium, phosphate, or macromolecules}

Using a glucose-based PDF, adjustment of body volume is one reason to choose APD [14] because the usage of a cycler machine can perform frequent and short-term changes of dialysate to obtain appropriate ultrafiltration. However, we also have to consider sodium removal with ultrafiltration because sodium sieving sometimes occurs, especially when using high-concentrated glucose PDF for a short dwell time $[17,18]$. Sodium sieving, first proposed by Rodriguez-Carmona et al., suggests that water removal is faster than sodium removal through ultrasmall pore (aquaporin-1) water channels [18]. In fact, there were a couple of reports showing that total sodium removal in patients on CAPD was more than that on APD, although total ultrafiltration on CAPD might be less than that on APD $[14,18]$. When Nakayama et al. reported the comparison of the efficacy of sodium removal among different concentrations of glucose-based PDFs with conventional sodium or low sodium concentration [17], sodium sieving was clearly observed in PD patients using high-concentrated glucose-based PDF over a short dwell time. Therefore, using high-glucose-concentrated dialysate and frequent bag changes with a short dwell time; removal of sodium might not be sufficient because of sodium sieving. In that case, ideally, options to remove an appropriate amount of sodium include increasing dwell time, combining with usage of icodextrin, not using highglucose dialysate, extending the dwell time of the cycler machine's program, and/or decreasing sodium intake [19].

Concerning the removal of large molecules of uremic toxin, it has been reported that the efficacy of CAPD is better than that of APD for the removal of $\beta 2$ microglobulin [20-23].

Therefore, the efficacy of the removal of sodium and large uremic molecules is better in CAPD patients with a long dwell time than in APD patients with frequent and short dwell times.

\section{Effects for RRF}

Preservation of residual renal function (RRF) is important to prevent lethal cardiovascular events in ESRD patients. It would be better to focus efforts on maintaining RRF in ESRD patients, even if they have chosen maintenance blood purification therapies, including hemodialysis [24]. In PD patients, it has been shown that life survival is better when the rate of decline in RRF is slower [25] and that preservation of RRF is an important factor in decreasing the risk of cardiovascular death [26]. In addition, PD patients who have chosen incremental PD might have better control of body fluid volume and removal of macromolecules, including preservation of RRF [27]. Therefore, it is important to make an effort to prevent factors that worsen RRF such as cautiously using large doses of loop diuretics, avoiding nephrotoxic drugs, minimizing use of frequent radiocontrast dyes, optimizing blood pressure control, using an angiotensin-converting enzyme inhibitor or angiotensin receptor blocker, avoiding hypotension and dehydration, selecting a biocompatible PD solution and/ or icodextrin-based PD solution, and preventing PDrelated peritonitis [28-30]. As part of incremental PD, low-frequency APD may be a good choice for ESRD patients [31].

However, it has been controversial whether APD or PD is better for preservation of RRF. Several cohort studies have approached this question. Recently, Bieber et al. summarized 20 cohort studies to compare the preservation of RRF between APD and CAPD in literature published between 1994 and 2011 [7], and most of them showed no differences in preservation of RRF between APD and CAPD. In 2015, when usage of APD was started from induction periods for 24 months, the decrease in RRF with APD was reported to be faster than that with CAPD in a multicenter cohort study from a Spanish group [32].

There were generally no differences in the method used for PD between APD and CAPD in most of the literature, but some results showed a slight advantage in the preservation of RRF for CAPD patients. One reason APD might be slightly less advantageous than CAPD, especially during induction periods, is the shorter dwell time and more frequent changes of PDF, which may result in excessive dehydration in patients on APD. Past reports are summarized in Table 2.

\section{Effects on incidence/recovery of PD-related peritonitis}

This point has also been controversial until now (Table 3). Briefly, APD may be better, or at least no worse, as far as the incidence of peritonitis compared with CAPD. In a meta-analysis [33], the incidence of peritonitis in patients with APD was lower than those with CAPD because the frequency of PD bag changes in APD was less than in CAPD, meaning that opportunities for contamination in APD were fewer. In contrast, there were several reports that showed no differences in the incidence of peritonitis between APD and CAPD [11]. In another review article, Bieber et al. summarized seven reports that compared the incidence of peritonitis between APD and CAPD. The review showed that three of the reports demonstrated no differences between APD and CAPD, two found APD to be more advantageous compared to CAPD, and one showed advantages of CAPD over APD before 2011 [7]. In a recent multicenter cohort report in Hong Kong [10], peritonitis-free survival in patients on APD was better than peritonitis-free survival in patients on CAPD for up to 2 years after starting PD therapy. Peritonitis-free survival was defined as the duration of PD until first occurrence of 
Table 2 Comparison between APD and CAPD for preservation of residual renal function

\begin{tabular}{|c|c|c|c|c|c|c|}
\hline Study (published year) & Study design & Setting countries & Data source & $N(C A P D, A P D)$ & Duration of observation & Results \\
\hline $\begin{array}{l}\text { de Fijter CW et al. (1994) } \\
\text { [15] }\end{array}$ & $\begin{array}{l}\text { Prospective } \\
\text { Randomized study }\end{array}$ & $\begin{array}{l}\text { Netherlands } \\
(1988-1991)\end{array}$ & Single & $81(41,41)$ & 24 months & Ns. \\
\hline $\begin{array}{l}\text { Hiroshige K et al. (1996) } \\
\text { [22] }\end{array}$ & $\begin{array}{l}\text { Prospective } \\
\text { cohort study }\end{array}$ & Japan (1992-1994) & Single center & $18(5,13)$ & 6 months & CAPD was better \\
\hline $\begin{array}{l}\text { Bro S et al. (1999) } \\
\text { [16] }\end{array}$ & $\begin{array}{l}\text { Prospective } \\
\text { randomized study }\end{array}$ & Denmark (1995-1999) & Multicenter & $34(17,17)$ & 6 months & Ns. \\
\hline $\begin{array}{l}\text { Hufnagel G et al. (1999) } \\
\text { [92] }\end{array}$ & $\begin{array}{l}\text { Prospective } \\
\text { cohort study }\end{array}$ & France (1995-1997) & Single center & $36(18,18)$ & 12 months & CAPD was better \\
\hline $\begin{array}{l}\text { Galler P et al. (2000) } \\
\text { [93] }\end{array}$ & $\begin{array}{l}\text { Prospective } \\
\text { cohort study }\end{array}$ & Spain (N/A) & Single center & $20(11,9)$ & 12 months & Ns. \\
\hline $\begin{array}{l}\text { Hamada C et al. (2000) } \\
\text { [94] }\end{array}$ & $\begin{array}{l}\text { Prospective } \\
\text { cohort study }\end{array}$ & Japan (N/A) & Single & $34(17,17)$ & 24 months & $\begin{array}{l}\text { Ns. (but decrease of urinary } \\
\text { volume was faster in CAPD) }\end{array}$ \\
\hline $\begin{array}{l}\text { Moist LM et al. (2000) } \\
\text { [95] }\end{array}$ & $\begin{array}{l}\text { National } \\
\text { Registry data }\end{array}$ & USA (1997) & $\begin{array}{l}\text { USRDS dialysis } \\
\text { morbidity } \\
\text { and mortality }\end{array}$ & $1032(722,310)$ & 8-18 months & Ns. \\
\hline $\begin{array}{l}\text { Singhal MK et al. (2000) } \\
\text { [96] }\end{array}$ & $\begin{array}{l}\text { Prospective } \\
\text { cohort study }\end{array}$ & Canada (1994-1997) & Single center & $242(211,31)$ & $27 \pm 14$ months & Ns. \\
\hline $\begin{array}{l}\text { Holley JL et al. (2001) } \\
\text { [97] }\end{array}$ & $\begin{array}{l}\text { Retrospective } \\
\text { database }\end{array}$ & USA (1991-2000) & $\mathrm{N} / \mathrm{A}$ & $184(70,114)$ & $<9$ months & Ns. \\
\hline $\begin{array}{l}\text { Hidaka H et al. (2003) } \\
\text { [98] }\end{array}$ & $\begin{array}{l}\text { Prospective } \\
\text { cohort study }\end{array}$ & Japan (1995-2001) & Single center & $34(27,7)$ & 12 42 months & CAPD was better \\
\hline $\begin{array}{l}\text { Johnson DW et al. (2003) } \\
\text { [99] }\end{array}$ & $\begin{array}{l}\text { Prospective } \\
\text { cohort study }\end{array}$ & Australia (1995-2001) & Single center & $146(134,12)$ & $21 \pm 15$ months & Ns. \\
\hline $\begin{array}{l}\text { Rodriguez-Carmona A et al. } \\
(2004) \text { [100] }\end{array}$ & $\begin{array}{l}\text { Prospective } \\
\text { observational study }\end{array}$ & Spain (1995-2001) & Single center & $104(53,51)$ & 12-24 months & CAPD was better \\
\hline $\begin{array}{l}\text { Balasubramanian et al. } \\
\text { (2011) [11] }\end{array}$ & $\begin{array}{l}\text { Retrospective } \\
\text { observational study }\end{array}$ & UK (2003-2008) & Single center & $277(130,147)$ & 5 years & Ns. \\
\hline $\begin{array}{l}\text { Cnossen TT et al. (2011) } \\
\text { [90] }\end{array}$ & $\begin{array}{l}\text { Retrospective } \\
\text { observational study }\end{array}$ & UK (2001-2008) & Multicenter & $620(179,441)$ & 450 days & Ns. \\
\hline $\begin{array}{l}\text { Michael WM et al. (2011) } \\
\text { [101] }\end{array}$ & $\begin{array}{l}\text { Prospective } \\
\text { cohort study }\end{array}$ & Netherlands (1997-2006) & $\begin{array}{l}\text { Multicenter } \\
\text { (NECOSAD) }\end{array}$ & $583(505,78)$ & 3 months-3 years & Ns. \\
\hline $\begin{array}{l}\text { Roszkowska-Blaim M et al. } \\
\text { (2012) [80] }\end{array}$ & $\begin{array}{l}\text { Retrospective } \\
\text { observational study }\end{array}$ & Poland (1992-2009) & Multicenter & 101 children $(44,57)$ & 36 months & CAPD was better \\
\hline $\begin{array}{l}\text { Pérez Fontán M et al. } \\
\text { (2015) [32] }\end{array}$ & $\begin{array}{l}\text { Retrospective } \\
\text { observational study }\end{array}$ & Spain (2000-2010) & Multicenter & $493(365,125)$ & 6-24 months & $\begin{array}{l}\text { CAPD was better when } \\
\text { APD was introduced during } \\
\text { induction period of PD }\end{array}$ \\
\hline
\end{tabular}

Ref. Bieber SD et al. [7]

Ns. not significant between CAPD and APD, N/A not available in the text, NECOSAD Netherlands Cooperative Study on the Adequacy of Dialysis, USRDA US Renal Data System 
Table 3 Comparison for effects on incidence of PD-related peritonitis between APD and CAPD

\begin{tabular}{|c|c|c|c|c|c|c|}
\hline Study (published year) & Study design & Setting countries & Data source & $\mathrm{N}(\mathrm{CAPD}, \mathrm{APD})$ & Duration of observation & Results \\
\hline $\begin{array}{l}\text { Alliapoulos JC et al. } \\
\text { (1984) [102] }\end{array}$ & Cross-sectional study & USA (N/A) & Single center & $\begin{array}{l}10 \text { pediatric patients } \\
\text { and subsequently CCPD. }\end{array}$ & $\begin{array}{l}15.0 \pm 2.8 \text { months for } \\
\text { CAPD vs. } 9.3 \pm 3.2 \text { months }\end{array}$ & Ns. \\
\hline $\begin{array}{l}\text { de Fijter CW et al. } \\
\text { (1994) [15] }\end{array}$ & $\begin{array}{l}\text { Prospective } \\
\text { randomized study }\end{array}$ & Netherlands (1988-1991) & Single center & $82(41,41)$ & 24 months & APD was better \\
\hline $\begin{array}{l}\text { Bro S et al. (1999) } \\
{[16]}\end{array}$ & $\begin{array}{l}\text { Prospective } \\
\text { randomized study }\end{array}$ & Denmark (1995-1999) & Multicenter & $34(17,17)$ & 6 months & $\begin{array}{l}2 \text { cases for CAPD, } \\
1 \text { case for APD }\end{array}$ \\
\hline Rodríguez-Carmona A et al. (1999) [103] & $\begin{array}{l}\text { Prospective } \\
\text { nonrandomized study }\end{array}$ & Spain (1989-1998) & Single center & $328(213,115)$ & 3 months -10 years & APD was better \\
\hline $\begin{array}{l}\text { Yishak A et al. (2001) } \\
\text { [104] }\end{array}$ & $\begin{array}{l}\text { Prospective } \\
\text { observational study }\end{array}$ & USA (1990-2000) & Multicenter & $583(384,199)$ & N/A & Ns. \\
\hline $\begin{array}{l}\text { Oo TN et al. (2005) } \\
\text { [105] }\end{array}$ & National registry data & US (1994-1997) & Multicenter & $11,975(9190,2785)$ & 6 months -2 years & APD was better \\
\hline $\begin{array}{l}\text { Davenport A. (2009) } \\
\text { [106] }\end{array}$ & $\begin{array}{l}\text { Observational } \\
\text { cross-sectional study }\end{array}$ & UK (2002-2003) & Multicenter & $\begin{array}{l}863(538,325) \text { at the } \\
\text { end of } 2002,(635,445) \\
\text { at the end of } 2003\end{array}$ & 2 years & APD was better \\
\hline $\begin{array}{l}\text { Nessim SJ et al. (2009) } \\
{[107]}\end{array}$ & $\begin{array}{l}\text { Prospective } \\
\text { cohort study }\end{array}$ & Canada (1996-2005) & Multicenter & $3180(N / A)$ & N/A & Ns. \\
\hline Balasubramanian G et al. (2011) [11] & $\begin{array}{l}\text { Retrospective } \\
\text { observational study }\end{array}$ & UK (2003-2008) & Single center & $372(178-194)$ & 5 years & APD was better \\
\hline $\begin{array}{l}\text { Rüger W et al. (2011) } \\
\text { [36] }\end{array}$ & $\begin{array}{l}\text { Retrospective } \\
\text { observational study }\end{array}$ & Netherlands (1993-2007) & Single center & $205(112,93)$ & 14 years & Ns. \\
\hline $\begin{array}{l}\text { Mizuno M et al. (2011) } \\
{[108]}\end{array}$ & $\begin{array}{l}\text { Retrospective } \\
\text { observational study }\end{array}$ & Japan (2005-2007) & Multicenter & $561(N / A)$ & N/A & Ns. \\
\hline $\begin{array}{l}\text { Lee OK et al. (2013) } \\
\text { [79] }\end{array}$ & $\begin{array}{l}\text { Retrospective } \\
\text { observational study }\end{array}$ & Korea (1986-2011) & Single center & $\begin{array}{l}57(51,6), \text { less than } \\
18 \text { years old }\end{array}$ & 6 months-240 months & $\begin{array}{l}\text { APD was better in } \\
\text { childhood }\end{array}$ \\
\hline $\begin{array}{l}\text { Kwan BC et al. (2013) } \\
{[10]}\end{array}$ & $\begin{array}{l}\text { Retrospectiv } \\
\text { observational study }\end{array}$ & Hong Kong (1995-2011) & Multicenter & $270(180,90)$ & 9.5 months -46.5 months & $\begin{array}{l}\text { APD was better for } \\
\text { induction period } \\
\text { of PD }\end{array}$ \\
\hline $\begin{array}{l}\text { Nishina M et al. (2013) } \\
\text { [109] }\end{array}$ & $\begin{array}{l}\text { Retrospective } \\
\text { cohort study }\end{array}$ & Japan (2001-2011) & Single center & $192(156,36)$ & 10 years & Ns. \\
\hline $\begin{array}{l}\text { Lan PG et al. (2014) } \\
\text { [34] }\end{array}$ & $\begin{array}{l}\text { Prospective } \\
\text { observational study }\end{array}$ & $\begin{array}{l}\text { Australia and New Zealand } \\
\text { (2003-2011) }\end{array}$ & $\begin{array}{l}\text { Multicenter } \\
\text { (ANZDATA) }\end{array}$ & $6959(2761,4198)$ & Mean 1.9 years & Ns. \\
\hline $\begin{array}{l}\text { Beduschi GC et al. (2015) } \\
\text { [12] }\end{array}$ & $\begin{array}{l}\text { Prospective } \\
\text { cohort study }\end{array}$ & Brazil (2004-2011) & Multicenter & $2890(1445,1445)$ & 5 years & $\begin{array}{l}\text { Ns. for time to first } \\
\text { episode of peritonitis }\end{array}$ \\
\hline $\begin{array}{l}\text { Mizuno M et al. (2016) } \\
{[35]}\end{array}$ & $\begin{array}{l}\text { Retrospective } \\
\text { observational study }\end{array}$ & Japan (2010-2012) & Multicenter & $200(119,81)$ & 3 years & Ns. \\
\hline
\end{tabular}

Ref. Bieber SD et al. [7]

Ns. no significant differences between CAPD and CAD, N/A not available in the text, ANZDATA Australia and New Zealand Dialysis and Transplant 
peritonitis. However, in 2014, no differences between APD and CAPD were reported with regard to the incidence of peritonitis [34]. Our recent reports also showed no differences between APD and CAPD [35].

Concerning the prognosis of PD-related peritonitis, it has been reported that a difference between APD and CAPD has not been observed [36]. In considering whether to continue using a cycler during treatment for PD peritonitis, the possible selection of antibiotics in APD was limited by the 2010 ISPD guideline [37-39], compared with CAPD therapy. However, when PD-related peritonitis occurs in patients treated with APD, we can transiently change the method of treatment from APD to CAPD until the patient recovers from peritonitis. Of note, it is important to keep in mind the possible difficulty in observing and recognizing slightly cloudy PDF in the early stage of peritonitis in APD therapy because the waste fluid tank might be easily soiled by the drainage of PDF.

From the past literature, it has been suggested that the decrease in the number of PDF bag changes might decrease opportunities for peritonitis caused by contamination in patients with APD. Especially during the early period of PD induction, APD might be associated with a lower incidence of peritonitis than CAPD. However, it remains unclear which method, APD or CAPD, is associated with an overall lower incidence of peritonitis. Large-scale prospective cohort studies might be required in the future to more clearly determine whether APD or CAPD is better.

\section{Effects associated with peritoneal leakage or herniation}

When abdominal pressures are increased, the risks of incidence of peritoneal leakage and/or herniation, such as incisional herniation, pericatheter herniation, umbilical herniation, and inguinal herniation, are increased $[40,41]$. It is well known that, in humans, abdominal pressure is the lowest in the supine position and the pressure increases in the sitting and standing positions [42]. After starting PD therapy, abdominal pressure in ESRD patients may increase, depending on the dwell volume of PDF in the abdomen [42, 43]. It was also reported that abdominal pressure was increased by coughing and constipation, which induce excessive straining, and by increased intraperitoneal volume of PDF [42]. Although there were some reports that intraperitoneal pressure was not dependent on intraperitoneal volume, the investigated volume was more than $2 \mathrm{~L}$ in these reports [41, 44]. In contrast, Twardowski et al. reported that abdominal pressure was observed to increase with the addition of $3 \mathrm{~L}$ of fluid to an empty abdomen [42].

Polycystic kidney disease (PKD) was reported as an independent risk factor for peritoneal leakage and herniation in PD patients $[41,45,46]$. In contrast, there was a report that showed no increase in the incidence of herniation in PKD patients [47]. Thus, which type of PD is better to decrease the risk of herniation in PD patients, APD or CAPD? In patients with $\mathrm{PKD}$, the incidence of herniation with APD treatment was less than in patients treated with CAPD [41]. On the other hand, Rabindranath et al. reported that the risk of herniation was not different between APD and CAPD in a meta-analysis [33]. Of note, because obesity has also been reported to increase intra-abdominal pressure $[42,43]$, extreme obesity might be a disadvantage to PD therapy due to the increased risk of peritoneal leakage and/ or herniation.

When abdominal pressure is increased in clinical situations such as PKD and obesity, one could theoretically choose to induce APD to prevent the development of peritoneal leakage and herniation. In fact, there have been several reports showing that APD had a lower rate of herniation than CAPD [41, 44], although other reports have shown no significant difference in the incidence of herniation with APD versus CAPD [48] (Table 4). However, the latter reports compared dwell volumes of more than $2 \mathrm{~L}$. Therefore, it may be useful to maintain only up to approximately $1 \mathrm{~L}$ to prevent an increase in abdominal pressure and to decrease the risk of peritoneal leakage and herniation in high-risk patients $[49,50]$. A Japanese report showed that intra-abdominal pressure was not significantly increased when dwell volume was less than $1 \mathrm{~L}$ in Japanese patients [51]. Because of this data, it may be suggested that a dwell volume of less than $1 \mathrm{~L}$ of PDF will prevent leakage/herniation, at least in the Japanese population.

\section{Influences on SAS and respiratory function}

Sleep disorders are common complications and factors that shorten life expectancy for ESRD patients due to the associated cardiovascular disease [52-55]. Sleep apnea syndrome (SAS) is a major cause of sleep disorder, hypertension, arrhythmias, and sudden death [56, 57]. Furthermore,

Table 4 Risk of incidence of peritoneal leakage and/or herniation between APD and CAPD

\begin{tabular}{|c|c|c|c|c|c|c|}
\hline $\begin{array}{l}\text { Study } \\
\text { (published year) }\end{array}$ & Study design & Setting countries & Data source & $N(C A P D, A P D)$ & Duration of observation & Results \\
\hline $\begin{array}{l}\text { Alliapoulos JC et al. } \\
(1984) \text { [102] }\end{array}$ & Cross-sectional study & USA (N/A) & Single center & $\begin{array}{l}10 \text { pediatric patients } \\
\text { and subsequently CCPD }\end{array}$ & $\begin{array}{l}15.0 \pm 2.8 \text { months for } \\
\text { CAPD vs. } 9.3 \pm 3.2 \text { months }\end{array}$ & $\begin{array}{l}\text { CAPD was higher } \\
\text { risk than APD but Ns }\end{array}$ \\
\hline $\begin{array}{l}\text { del Peso G et al. } \\
(2003)[48]\end{array}$ & $\begin{array}{l}\text { Retrospective } \\
\text { observational study }\end{array}$ & $\begin{array}{l}\text { Spain } \\
(1995-2000)\end{array}$ & Single center & $\begin{array}{l}80(72,8) 62 \text { with } \\
\text { both modalities }\end{array}$ & 5 years & $\begin{array}{l}\text { CAPD was higher } \\
\text { risk than APD but Ns }\end{array}$ \\
\hline
\end{tabular}

Ns. not significant differences between CAPD and CAD, N/A not available in the text 
concerning SAS, it has been reported that the number of apnea/hypopnea episodes per hour of sleep was suppressed by induction of APD compared with CAPD [58]. They especially mentioned that APD might be more effective for obstructive apnea/hypopnea when SAS is diagnosed in PD patients. However, Sydney et al. reported that SAS was an independent risk factor for subsequent mortality and cardiovascular events when ESRD patient had SAS at the start of PD [59]. Diagnosis and subsequent therapy may be required to decrease mortality.

With regard to respiratory disease, which type of PD therapy is a better choice for patients with severe pulmonary disease, APD or CAPD? It is thought that PD is relatively contraindicated in ESRD patients with severe pulmonary disease $[60,61]$. In contrast, some reports have shown that induction of CAPD did not worsen respiratory function [62,63]. It is therefore not certain which is better, APD or CAPD, in ESRD patients with severe pulmonary disease. A position change from sitting to supine position was reported to decrease $10 \%$ of functional residual capacity and increase closing volume under CAPD therapy $[63,64]$. It might be suggested that APD is better than CAPD in severe pulmonary disease, although it is still unclear whether or not it might be suitable to select $\mathrm{PD}$ as renal replacement therapy.

\section{Which is more suitable, APD or CAPD, to improve health-related QoL in physical, psychological, and social activity? \\ Effects for health-related QoL}

We believe that current treatment with induction of APD can relieve PD patients from rushing to perform repeated daily bag changes, thus allowing more free time. It was expected that APD might be better than CAPD with regard to physical, psychological, and/or social activities of
PD patients. Some studies were evaluated using mental composite scores and physical composite scores in the comparison of APD and CAPD. Surprisingly, most published reports, including prospective cohort studies and RCT studies, showed no significant differences in healthrelated quality of life (QoL) or depression in PD patients treated with either APD or CAPD [11, 65]. In a review published by Bieber et al. in 2014, several of those reports concerning health-related QoL were summarized [7]. They described that the health-related QoL of ESRD patients was not different between APD and CAPD. For QoL of caregivers, APD might be better than CAPD [66] (Table 5).

\section{Quality of sleep for APD}

Disturbance of sleep might occur more frequently with APD than with CAPD. One reason may be the cycler's loud beeping to alert PD patients. The alert is necessary to wake up PD patients in order to resolve any trouble and continue APD therapy. However, although one might expect APD to decrease the quality of sleep $[16,65]$, there were no significant disadvantages of APD noted with regard to sleep disorders compared to CAPD in previous reports [7, 67, 68]. In fact, both APD and CAPD may equally worsen poor sleep quality [65].

\section{Aspect of medical economics in the selection of APD or CAPD}

Compared with CAPD, APD is more expensive. In a report from Denmark in 1999, the running cost for APD was shown to be $123 \%$ of CAPD [16]. The cost of APD was $139 \%$ of that of CAPD in a UK report from the National Health Service [69]. In Spain, it was reported that the cost of APD was approximately 136 to $160 \%$ of CAPD [70]. Japan is not exceptional with regard to the

Table 5 Comparison between APD and CAPD for health-related quality of life and sleep

\begin{tabular}{|c|c|c|c|c|c|c|}
\hline Study (published year) & Study design & Setting countries & Data source & $N(C A P D, A P D)$ & $\begin{array}{l}\text { Duration of } \\
\text { observation }\end{array}$ & Results \\
\hline Bro S et al. (1999) [16] & $\begin{array}{l}\text { Randomized } \\
\text { controlled study }\end{array}$ & $\begin{array}{l}\text { Denmark } \\
(1995-1999)\end{array}$ & Multicenter & $34(17,17)$ & 6 months & $\begin{array}{l}\text { APD was better for QoL } \\
\text { but more problem for } \\
\text { sleep disturbance }\end{array}$ \\
\hline $\begin{array}{l}\text { de Wit GA et al. } \\
\text { (2001) [67] }\end{array}$ & Cross-sectional study & $\begin{array}{l}\text { Netherlands } \\
\text { (1993-2001) }\end{array}$ & $\begin{array}{l}\text { Multicenter, } \\
\text { (NECOSAD) }\end{array}$ & $96(59,37)$ & N/A & APD was better \\
\hline Sunder S et al. (2008) [68] & $\begin{array}{l}\text { Prospective } \\
\text { observational study }\end{array}$ & India (N/A) & Single center & 18 & 12 months & Ns. \\
\hline Guney I et al. (2010) [65] & Cross-sectional study & Turkey (N/A) & Single center & $68(48,20)$ & N/A & Ns. \\
\hline $\begin{array}{l}\text { Balasubramanian G et al. } \\
\text { (2011) [11] }\end{array}$ & $\begin{array}{l}\text { Retrospective } \\
\text { observational study }\end{array}$ & UK (2003-2008) & Single center & $224(111,131)$ & 5 years & Ns. \\
\hline $\begin{array}{l}\text { Michels WM et al. } \\
\text { (2011) [101] }\end{array}$ & $\begin{array}{l}\text { Prospective } \\
\text { cohort study }\end{array}$ & $\begin{array}{l}\text { Netherlands } \\
(1997-2006)\end{array}$ & $\begin{array}{l}\text { Multicenter } \\
\text { (NECOSAD) }\end{array}$ & $550(486,64)$ & 3 months -3 years & Ns. \\
\hline $\begin{array}{l}\text { Losso RL et al. (2015) } \\
\text { [110] }\end{array}$ & $\begin{array}{l}\text { Observational } \\
\text { cross-sectional study }\end{array}$ & $\begin{array}{l}\text { Curitiba, Parana, } \\
\text { Brazil (N/A) }\end{array}$ & Multicenter & $76(48,28)$ & N/A & Ns. \\
\hline
\end{tabular}

Ref. Bieber SD et al. [7]

Ns. not significant differences between CAPD and CAD, N/A not available in the text, NECOSAD Netherlands Cooperative Study on the Adequacy of Dialysis 
expenses associated with APD. Now, as we face an aging society, annual medical expenses may be further expanded in the future worldwide [71, 72]. We may need to balance the medical and social benefits for each individual PD patient with cost performance. Because APD is significantly more expensive than CAPD, when APD is the preferred choice, it may be better to perform intermittent PD with APD in order decrease the number of APD exchanges. However, to perform intermittent PD alternating with APD, preservation of RRF and control sodium intake might be required and decrease overall cost as the result [73].

\section{Other advantages and disadvantages of APD}

PD patients often prefer APD because another advantage is the lessened amount of time required from caregivers $[14,74]$. Particularly, APD may be a good choice for caregivers of disabled PD patients [74]. On the other hand, manufacturer's instructions for handling of cyclers may be complicated compared with CAPD. Additionally, if a natural disaster occurs and lifelines including electricity are stopped, CAPD can work more easily than hemodialysis [75, 76]. When the great East Japan earthquake happened and the delivery of both electrical supply and water supply stopped, PD patients could still continue CAPD therapy [77]. However, cyclers require electricity because they do not have batteries. Therefore, CAPD is more efficient during natural disasters, compared with APD. Cyclers for APD are generally heavy and require delicate precision and are thus not suitable for easy carrying. Making space for a cycler and its related equipment in a patient's house is required to initiate APD.

\section{Advantages of APD for children}

Until now, there have not been enough reports to recommend selection between APD and CAPD. Generally, induction of APD may be considered in children with ESRD, especially small children who are cared for by their family [66] and can attend school without the need to perform bag exchanges [78]. Comparing children on CAPD with children on CCPD with a cycler, the removal of creatinine, urea, and phosphates is similar and dependent on dwell time and PD volume [66]. To decrease the incidence of peritonitis in younger children, Lee et al. reported that APD was better than CAPD [79]. Therefore, APD may also be important to decrease the risk of bag change contamination for younger children or their caregivers. In contrast, Roszkowska-Blaim et al. showed that RRF was preserved in CAPD more than in APD in children on PD [80]. As another interesting point, analysis of health-related QoL of caregivers, such as patients' parents, was reported. However, even if using APD, it was commented that children's parents might still have felt physiological and emotional stressrelated to supporting their children [81].

Briefly, as the 2011 NICE guideline in the UK recommends, APD may be offered for children, especially those with low RRF [82]. However, it is important to keep in mind that APD may allow reduction of RRF more rapidly than CAPD.

\section{Expectations for APD in the future}

A first-generation cycler, the Pac-X cycler II (Baxter), was too large for Japanese houses. After that, cycler machines for APD became more compact and were also functionally improved. In Japan, the home APD systems YUME and YUME plus, My home $\mathrm{PICO}^{\circ}$ APD system, PD-mini Neo APD system, and Sleepsafe ${ }^{\circ}$ APD system were developed by Baxter Limited, TERUMO Co. (Tokyo, Japan), JMS Co. (Tokyo, Japan) and Fresenius Medical Care Japan (Tokyo, Japan), respectively. Recent cycler machines used in Japan are able to store APD medical records, monitor the time course, and review it later, and the cycler machine can output measurements of body weight and blood pressure (APD system PD-Mini Neo, JMS Co.). However, the manufacturer's information is still complicated and PD patients are required to learn these procedures when a cycler machine is introduced. It might be especially difficult to introduce a cycler machine for disabled patients, especially those with blindness or hearing loss, as well as with older patients. In order to induce APD for patients with hearing loss, a telemetry system as a communication tool might be useful [83].

As a future cycler machine, Bieber et al. described the potential development of a cycler for APD that should be simpler to use and which has a large touchscreen, sterile connecting system, voice operated controls, a data sharing function between patients and medical staff, improved safety, and better cost performance [7]. In Japan, Nakamoto proposed a telemedicine system to manage outpatients on PD therapy at home [84]. In the future, a remote-controlled cycler machine may be developed.

At present, many machines are improving worldwide. Hopefully in the future, a cycler machine for APD will be developed that would enable the user to set everything automatically with one touch, and no complicated procedures for how to use the cycler machine will need to be learned.

\section{Conclusions}

At this moment, we still have not had enough evidence to say which is better, APD or CAPD, for every patient on PD therapy; and patient and physician preference may be important in choosing APD. We still need to consider which may be better between APD and CAPD on an individual basis based on medical, socioeconomic, and emotional aspects. Clinically, APD may be a better choice in 
infants and young children, although more supporting data is needed. Assisted APD may be a better choice for older patients who require caregiver support. It is also important to consider each patient's preference in the decision to introduce the cycler for APD.

\section{Abbreviations}

$A P D$, automated peritoneal dialysis; CAPD, continuous ambulatory peritoneal dialysis; CCPD, continuous cycling peritoneal dialysis; ESRD, end-stage renal disease; PD, peritoneal dialysis; PDF, peritoneal dialysate fluid; PET, peritoneal equilibration test; PKD, polycystic kidney disease; QoL, quality of life; RRF, residual renal function; SAS, sleep apnea syndrome

\section{Acknowledgements}

The authors thank Dr. M. Nakayama and Dr. M. Kubota for the opportunity to write this review article.

\section{Funding}

This work was supported by the 21th annual meeting of the Japanese Society for Peritoneal Dialysis.

\section{Availability of data and materials}

None.

\section{Authors' contributions}

MM designed and drafted the manuscript. YS, FA and YI helped to draft the manuscript. All authors read and approved the final manuscript.

\section{Competing interests}

Mizuno M, Suzuki Y, and Ito Y worked in the Department of Renal Replacement Therapy as positions endowed by Baxter Japan at Nagoya University Graduate School of Medicine.

\section{Consent for publication}

All authors have contributed for this manuscript. This manuscript has been read and approved for submission by all authors and is not under review elsewhere.

\section{Ethics approval and consent to participate}

Not available because this manuscript is a review.

\section{Received: 9 May 2016 Accepted: 21 July 2016}

\section{Published online: 21 September 2016}

\section{References}

1. Tenckhoff $H$, Schechter $H$. A bacteriologically safe peritoneal access device Trans Am Soc Artif Intern Organs. 1968;14:181-7.

2. Boen ST, Mion CM, Curtis FK, Shilipetar G. Periodic peritoneal dialysis using the repeated puncture technique and an automated cycling machine. Trans Amer Soc Artif Int Oegans. 1964;10:409-14

3. Tenckhoff H, Meston B, Shilipetar G. A simplified automatic peritoneal dialysis system. Trans Am Soc Artif Intern Organs. 1972;18:436-40.

4. Drukker W. 21: Peritoneal dialysis: a historical review, 2nd, revised and enlarged edition edn. Dordrecht: Martinus Nijhoff Publishers; 1986.

5. Oreopoulos DG. Ambulatory peritoneal dialysis. Lancet. 1978;23:686-7.

6. Sweeny J, Bernardo AA. Chaper 4D Bater Travenol hemodialys and peritoneal dialysis devices. Singapore: World Scientific Publishing Co.; 2012.

7. Bieber SD, Burkart J, Golper TA, Teitelbaum I, Mehrotra R. Comparative outcomes between continous ambulatory and automated peritoneal dialysis: a narrative review. Am J Kidney Dis. 2014;63:1027-37.

8. Sanchez AR, Madonia C, Rascon-Pacheco RA. Improved patient/technique survival and peritonitis rates in patients treated with automated peritoneal dialysis when compared to continuous ambulatory peritoneal dialysis in a Mexican PD center. Kidney Int. 2008;108:S76-80.

9. Mehrotra R. Long-term outcomes in automated peritoneal dialysis: similar or better than in continuous amburatory peritoneal dialysis? Perit Dial Int. 2009;29:S111-4.

10. Kwan BC, Chow KM, Ma TK, Yu V, Law MC, Leung CB, Li PK, Szeto CC. Automated peritoneal dialysis in Hong Kong: there are two distinct groups of patients. Nephrology. 2013;18:356-64.
11. Balasubramanian G, MCKitty K, Fan SLS. Comparing automated peritoneal dialysis with continous amburatory peritoneal dialysis: survival and quality of life differences? Nephrol Dial Transplant. 2011;26:1702-8.

12. Beduschi GC, Figueiredo AE, Olandoski M, Pecoits-Filho R, Barretti $P$, de Moraes TP, all centers that contributes to the BRAZPD. Automated peritoneal dialysis is associated with better survival rates compared to continuous ambulatory peritoneal dialysis: a propensity score matching analysis. Plos One. 2015;10:e0134047.

13. Johnson DW, Hawley CM, McDonald SP, Brown FG, Rosman JB, Wiggins KJ, Bannister KM, Badve SV. Superior survival of high transporters treated with automated versus continous amburatory peritoneal dialysis. Nephrol Dial Transplant. 2010;25:1973-9.

14. Virga G. A comparison between continous ambulatory and automated peritoneal dialysis. J Nephrol. 2013;26:S140-58.

15. de Fijter CW, Oe LP, Nauta JJ, van der Meulen J, Verbrugh HA, Verhoef J Donker AJ. Clinical efficacy and morbidity associated with continuous cyclic compared with continuous ambulatory peritoneal dialysis. Ann Intern Med. 1994;120:264-71.

16. Bro S, Bjorner JB, Tofte-Jensen P, Klem S, Almtoft B, Danielsen H, Meincke M, Friedberg M, Feldt-Rasmussen B. A Prospective, randomized multicenter study comparing and APD and CAPD treatment. Perit Dial Int. 1999;19:526-33.

17. Nakayama M, Kasai K, Imai H, TRM-280 Study Group. Novel low Na peritoneal dialysis solutions designed to optimize Na gap of effluent: kinetics of $\mathrm{Na}$ and water removal. Perit Dial Int. 2009:29:528-35.

18. Rodríguez-Carmona A, Miguel Pérez Fontán M. Soudium removal in patients undergoing CAPD and automated peritoneal dialysis. Perit Dial Int. 2002;22:705-13.

19. Boudville NC, Cordy P, Millman K, Fairbairn L, Sharma A, Lindsay R, Blake G. Blood pressure, volume, and sodium control in an automated peritonea dialysis population. Perit Dial Int. 2007;27:537-43

20. Evenepoel P, Bammens B, Verbeke K, Vanrenterghem Y. Superior dialytic clearance of B2-microglobulin and p-cresol by high-flux hemodialysis as compared to peritoneal dialysis. Kidney Int. 2006;70:794-9.

21. Lee SK, Kim DJ, Moon JH, et al. Peritoneal transport characteristics and pertoneal clearance of beta2-microglobulin. Korean J Nephrol. 1999;18:599-605.

22. Hiroshige K, Yuu K, Soejima M, Takasugi M, Kuroiwa A. Rapid decline of residual renal function in patients on automated peritoneal dialysis. Perit Dial Int. 1996;16:307-15.

23. Eloot S, Vanholder R, Dequidt C, Van Biesen W. Removal of different classes of uremic toxins in APD vs CAPD: a randomized cross-over study. Perit Dial Int. 2015:35:436-42.

24. Shemin D, Bostom AG, Laliberty P, Dworkin LD. Residual renal function and mortality risk in hemodialysis patients. Am J Kidney Dis. 2001;38:85-90.

25. Lu YH, Hwang JC, Jiang MY, Wang CT. Comparison of the impact of "fast decline" in residual renal function and "initial anuria" on long-term outcomes in CAPD patients. Perit Dial Int. 2015;35:172-9.

26. Wang AY, Wang M, Woo J, Lam CW, Lui SF, Li PK, Sanderson JE. Inflammation, residual kidney function, and cardiac hypertrophy are interrelated and combine adversely to enhance mortality and cardiovascular death risk of peritoneal dialysis patients. J Am Soc Nephrol. 2004;15:2186-94.

27. Viglino G, Neri L, Barbieri S. Incremental peritoneal dialysis: effects on the choice of dialysis modality, residual renal function and adequacy. Kidney Int Suppl. 2008;108:S52-5.

28. Li PK, Cheng YL. Therapeutic options for preservation of residual renal function in patients on peritoneal dialysis. Kidney Int. 2007;27:S158-63.

29. Marrón B, Remón C, Pérez-Fontán M, Quirós P, Ortíz A. Benefits of preserving residual renal function in peritoneal dialysis. Kidney Int 2008;73:S42-51.

30. Nongnuch A, Assanatham M, Panorchan K, Davenport A. Strategies for preserving residual renal function in peritoneal dialysis patients. Clin Kisney J. 2015:8:202-11.

31. Neri L, Viglino G, Cappelletti A, Gandolfo C, Barbieri S. Incremental dialysis with automated peritoneal dialysis. Adv Perit Dial. 2003;19:93-6.

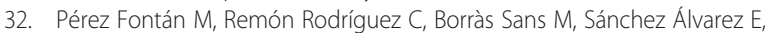
da Cunha NM, Quirós Ganga P, López-Calviño B, Rodríguez Suárez C, Rodriguez-Carmona A. Compared decline of residual kidney function in patients treated with automated peritoneal dialysis and continuous ambulatory peritoneal dialysis: a multicenter study. Nephron Clin Pract. 2015;128:352-60. 
33. Rabindranath KS, Adams J, Ali TZ, Daly C, Vale L, Macleod AM. Automated vs continuous ambulatory peritoneal dialysis: a systematic review of randomized controlled trials. Nephrol Dial Transplant. 2007;22:2991-8.

34. Lan PG, Johnson DW, McDonald SP, Boudville N, Borlace M, Badve SV, Sud K, Clayton PA. The association between peritoneal dialysis modality and peritonitis. Clin J Am Soc Nephrol. 2014;9:1091-7.

35. Mizuno M, Ito Y, Suzuki Y, Sakata F, Saka Y, Hiramatsu T, Tamai H, Mizutani M, Naruse T, Ohashi N et al. Recent analysis of status and outcomes of peritoneal dialysis in the Tokai area of Japan: the second report of the Tokai peritoneal dialysis registry. Clin Exp Nephrol. 2016, in press.

36. Rüger W, van Ittersum FJ, Comazzetto LF, Hoeks SE, ter Wee PM. Similar peritonitis outcome in CAPD and APD patients with dialysis modality continuation during peritonitis. Perit Dial Int. 2011;31:39-47.

37. Diaz-Buxo JA, Crawford TL, Bailie GR. Peritonitis in automated peritoneal dialysis: antibiotic therapy and pharmacokinetics. Perit Dial Int. 2001;21:S197-201.

38. Manley HJ, Bailie GR. Treatment of peritonitis in APD: pharmacokinetic principles. Semin Dial. 2002;15:418-21.

39. Li PK, Szeto CC, Piraino B, Bernardini J, Fiqueiredo AE, Gupta A, Johnson DW, Kuijper EJ, Lye WC, Salzer W, et al. Peritoneal dialysisrelated infections recommendations: 2010 update. Perit Dial Int. 2010;30:393-423.

40. Bargman JM. Complications of peritoneal dialysis related to increased intra-abdominal pressure. Kidney Int. 1993;40:575-80.

41. del Peso G, María Auxiliadora Bajo MA, Costero O, Hevia C, Gil F, Díaz C, Aguilera A, Selgas R. Risk factors for abdominal wall complications in peritoneal dialysis patients. Perit Dial Int. 2003;249-254.

42. Twardowski ZJ, Khanna R, Nolph KD, Scalamogna A, Metzler MH, Schneider TW, Prowant BF, Ryan LP. Intraabdominal pressures during natural activities in patients treated with continuous ambulatory peritoneal dialysis. Nephron. 1986:44:129-35.

43. Dejardin A, Robert A, Goffin E. Intraperitoneal pressure in PD patients: relationship to intraperitoneal volume, body size and PD-related complications. Nephrol Dial Transplant. 2007;22:1437-44.

44. Hussain SI, Bernardini J, Piraino B. The risk of hernia with large exchange volumes. Adv Perit Dial. 1998;14:105-7.

45. Modi KB, Grant AC, Garret A, Rodger RS. Indirect inguinal hernia in CAPD patients with polycystic kidney disease. Adv Perit Dial. 1989;5:84-6.

46. Morris-Stiff G, Coles G, Moore R, Jurewicz A, Lord R. Abdominal wall hernia in autosomal dominant polycystic disease. Br J Surg. 1997;84:615-7.

47. Hadimeri H, Johansson A-C, Haraldsson B, Nyberg G. CAPD in patients with autosomal dominant polycystic kidney disease. Perit Dial Int. 1998;18:429-32.

48. del Peso G, Auxiliadora Bajo MA, Costero O, Hevia C, Gil F, Díaz C, Aguilera A, Selgas R. Risk factors for abdominal wall complications in peritoneal dialysis patients. Perit Dial Int. 2003;23:249-54.

49. Tast C, Kuhlmann U, Stölzing H, Alscher D, Mettang T. Continuing CAPD after herniotomy. EDTNA ERCA J. 2002;28:173-5.

50. Shah H, Chu M, Bargman JM. Perioperative management of peritoneal dialysis patients undergoing hernia surgery without the use of interim hemodialysis. Perit Dial Int. 2006;26:684-7.

51. Kumano K, Sakai T, Yamashita A. A adequate volume of infusion and frequency of dialysate exchange on automated peritoneal dialysis. Jpn J Artif Organs. 1992;21:893-7.

52. Zoccali C, Mallamaci F, Tripepi G. Traditional and emerging cardiovascular risk factors in end-stage renal disease. Kidney Int. 2003;85:S105-10.

53. Iseki K, Tsuruya K, Kanda E, Nomura T, Hirakata H. Effects of sleepiness on survival in Japanese hemodialysis patients: J-DOPPS study. Nephron Clin Pract. 2014;128:333-40.

54. Ezzat H, Mohab A. Prevalence of sleep disorders among ESRD patients. Ren Fail. 2015;37:1013-9.

55. Mavanur M, Sanders M, Unruh M. Sleep disordered breathing in patients with chronic kidney disease. Indian J Med Res. 2010;131:277-84.

56. Parati G, Ochoa JE, Bilo G, Mattaliano P, Salvi P, Kario K, Lombardi C. Obstructive sleep apnea syndrome as a cause of resistant hypertension. Hypertens Res. 2014;37:601-13.

57. Shamsuzzaman AS, Somers VK, Knilans TK, Ackerman MJ, Wang Y, Amin RS Obstructive sleep apnea in patients with congenital long QT syndrome: implications for increased risk of sudden cardiac death. Sleep. 2015;38:1113-9.

58. Tang SC, Lam B, Ku PP, Leung WS, Chu CM, Ho YW, Ip MS, Lai KN. Alleviation of sleep apnea in patients with chronic renal failure by nocturnal cycler-assisted peritoneal dialysis compared with conventional continuous ambulatory peritoneal dialysis. J Am Soc Nephrol. 2006;17:2607-16.
59. Tang SC, Lam B, Yao TJ, Leung WS, Chu CM, Ho YW, Ip MS, Lai KN. Sleep apnea is a novel risk preditor of cardiovasular morbidity and death in patients receiving peritoneal dialysis. Kidney Int. 2010;77:1031-8.

60. Winchester JF. Peritoneal dialysis and pulmonary function. Chest. 1984;88:806-7.

61. Khanna R, Nolph KD, Oreopulos DG. Techniques prescriptions and indications. In: Khanna R, Nolph KD, Oreopoulos DG, editors. The essentials of peritoneal dialysis. Dordrecht: Academic; 1993. p. 35-44.

62. Singh S, Dale A, Morgan B, Sahebjami H. Pulmonary function tests in patients on continuous ambulatory peritoneal dialysis. Amsterdam: Excerpta Medica; 1981.

63. Leblanc M, Ouimet D, Tremblay C, Nolin L. Peritoneal instillation test before CAPD in a case of severe pulmonary disease. Perit Dial Int. 1995;15:384-7.

64. Winchester JF, Da Silva AMT, Davis W, Weir C, Barnard W, Rakowski TA, et al. Altered pulmonary function with continuous ambulatory peritoneal dialysis, vol. 1981. Amsterdam: Excerpta Medica; 1981.

65. Guney I, Solak H, Yazici R, Altintepe L, Kara F, Yeksan M, Turk S. Comparison of effetcs of automated peritoneal dialysis and continuous amburatory peritoneal dialysis on health-related quality of life, sleep quality, and depression. Hemodial Int. 2010;14:515-22.

66. Balfe JW. Comparison of CAPD and CCPD in children and their limitations. Saudi J Kidney Dis Transplant. 1994;5:173-8.

67. de Wit GA, Merkus MP, Krediet RT, de Charro FT. A comparison of quality of life of patients on automated and continuous ambulatory peritoneal dialysis. Perit Dial Int. 2001;21:306-12.

68. Sunder S, Kalra OP, Nashine S, Waghmare V, Ruchi R. Comparative study of adequacy of dialysis and health-related quality of life in patients on CAPD and APD. Perit Dial Int. 2008;28:542-4.

69. Baboolal K, McEwan P, Sondhi S, Spiewanowski P, Wechowski J, Wilson K. The cost of renal dialysis in a UK setting - a multicentre study. Nephrol Dial Transplant. 2008;23:1982-9.

70. Lamas Barreiro JM, Alonso Suárez M, Saavedra Alonso JA, Gándara Martínez A. Costs and added value of haemodialysis and peritoneal dialysis outsourcing agreements. Nefrologia. 2011;31:656-63.

71. Brunkhorst R, Wrenger E, Krautzig S, Ehlerding G, Mahiout A, Koch KM. Clinical experience with home automated peritoneal dialysis. Kidney Int. 1994;46:S25-30.

72. Johnson D, Brown F, Lammi H, Walker R. Caring for Australians with renal impairment (CARI). The CARI guidelines. Dialysis adequacy (PD) guidelines. Nephrology. 2005;10:S81-S107.

73. Guest S, Akonur A, Ghaffari A, Sloand J, Leypoldt JK. Intermittent peritoneal dialysis: urea kinetic modeling and implications of residual kidney function. Perit Dial Int. 2012;32:142-8.

74. Dombros N, Dratwa M, Feriani M, Gokal R, Heimbürger $O$, Krediet R, Plum J, Rodrigues A, Selgas R, Struijk D, et al. European best practice guidelines for peritoneal dialysis. 6 Automated peritoneal dialysis. Nephrol Dial Transplant. 2005;20:ix21-3.

75. Kleinpeter MA. Disaster preparedness for dialysis patients. Clin J Am Soc Nephrol. 2011;6:2337-9.

76. Gray NA, Wolley M, Liew A, Nakayama M. Natural disasters and dialysis care in the Asia-Pacific. Nephrology. 2015;20:873-80.

77. Kumagai N. Managing children who reqire peritoneal dialysis at the Tohoku University Hospital department of pediatrics immediately after the Great Easrern Japan Earthquake. Nihon Shoni Jinzobyo Gakkai Zasshi. 2015;28:134-9.

78. Liakopoulos $V$, Dombros N. Patient selection for automated peritoneal dialysis: for whom, when? Perit Dial Int. 2009;29:S102-7.

79. Lee KO, Park SJ, Kim JH, Lee JS, Kim PK, Shin Jl. Outcomes of peritonitis in children on peritoneal dialysis: a 25-year experience at Severance Hospital. Yonsei Med J. 2013;54:983-9.

80. Roszkowska-Blaim M, Skrzypczyk P, Jander A, Tkaczyk M, Bałasz-Chmielewska I, Zurowska A, Drozdz D, Pietrzyk JA. The effect of peritoneal dialysis method on residual renal function in children. Adv Perit Dial. 2012;28:112-9.

81. Kiliś-Pstrusińska K, Wasilewska A, Medyńska A, Bałasz-Chmielewska I, Grenda R, Kluska-Jóźwiak A, Leszczyńska B, Olszak-Szot l, Miklaszewska M, Szczepańska M, et al. Psychosocial aspects of children and families of children treated with automated peritoneal dialysis. Pediatr Nephrol. 2013;28:2157-67.

82. National Institute for health and clinical excellence. Peironeal dialysis. Perioneal dialysis in the treatment of stage 5 chronic kidney disease. In: NICE clinical guideline 125 developed by the centre for clinical practice at NICE. UK: National Institute for health and clinical excellence; 2011. 
83. Sakurada T, Kojima S, Oishi D, Koitabashi K, Shibagaki Y, Kimura K. Automated peritoneal dialysis for a patient with hearing loss: a case report. Perit Dial Int. 2015;35:229-35.

84. Nakamoto H. Telemedicine system for patients on contiuous amburatory peritoneal dialysis. Perit Dial Int. 2007;27:S21-6.

85. Guo A, Mujais S. Patient and technique survival on peritoneal dialysis in the United States: evaluation in large incident cohorts. Kidney Int Suppl. 2003;88:S3-S12.

86. Badve SV, Hawley CM, McDonald SP, et al. Automated and continuous ambulatory peritoneal dialysis have similar outcomes. Kidney Int. 2008;73: 480-8.

87. Liao CT, Shiao CC, Huang JW, et al. Predictors of faster decline of residual renal function in Taiwanese peritoneal dialysis patients. Perit Dial Int 2008;28 suppl 3:S191-5.

88. Mehrotra R, Chiu YW, Kalantar-Zadeh K, Vonesh E. The outcomes of continuous ambulatory and automated peritoneal dialysis are similar. Kidney Int. 2009;76:97-107.

89. Michels WM, Verduijn M, Boeschoten EW, Dekker FW, Krediet RT, Group NS. Similar survival on automated peritoneal dialysis and continuous ambulatory peritoneal dialysis in a large prospective cohort. Clin J Am Soc Nephrol. 2009:4:943-9.

90. Cnossen T, Usvyat L, Kotanko P, et al. Comparison of outcomes on continuous ambulatory peritoneal dialysis versus automated peritoneal dialysis: results from a USA database. Perit Dial Int. 2011;31:679-84.

91. Sun CY, Lee CC, Lin YY, Wu MS. In younger dialysis patients, automated peritoneal dialysis is associated with better long-term patient and technique survival than is continuous ambulatory peritoneal dialysis. Perit Dial Int. 2011:31:301-7

92. Hufnagel G, Michel C, Queffeulou G, Skhiri H, Damieri H, Mignon F. The influence of automated peritoneal dialysis on the decrease in residual renal function. Nephrol Dial Transplant. 1999;14:1224-8.

93. Gallar P, Ortega O, Carreno A, Vigil A. Rate of decline in residual renal function is equal in CAPD and automated peritoneal dialysis patients. Perit Dial Int. 2000;20:803-5.

94. Hamada C, Osada S, Inoue S, et al. Effects of automated peritoneal dialysis on residual urinary volume. Perit Dial Int. 2000;20:239-41.

95. Moist LM, Port FK, Orzol SM, et al. Predictors of loss of residual renal function among new dialysis patients. J Am Soc Nephrol. 2000;11:556-64.

96. Singhal MK, Bhaskaran S, Vidgen E, Bargman JM, Vas SI, Oreopoulos DG. Rate of decline of residual renal function in patients on continuous peritoneal dialysis and factors affecting it. Perit Dial Int. 2000;20:429-38.

97. Holley JL, Aslam N, Bernardini J, Fried L, Piraino B. The influence of demographic factors and modality on loss of residual renal function in incident peritoneal dialysis patients. Perit Dial Int. 2001;21:302-5.

98. Hidaka $H$, Nakao T. Preservation of residual renal function and factors affecting its decline in patients on peritoneal dialysis. Nephrology. 2003:8:184-91.

99. Johnson DW, Mudge DW, Sturtevant JM, et al. Predictors of decline of residual renal function in new peritoneal dialysis patients. Perit Dial Int. 2003;23:276-83.

100. Rodriguez-Carmona A, Perez-Fontan M, Garca-Naveiro R, Villaverde P Peteiro J. Compared time profiles of ultrafiltration, sodium removal, and renal function in incident CAPD and automated peritoneal dialysis patients. Am J Kidney Dis. 2004;44:132-45.

101. Michels WM, Verduijn M, Grootendorst DC, et al. Decline in residual renal function in automated compared with continuous ambulatory peritoneal dialysis. Clin J Am Soc Nephrol. 2011;6:537-42.

102. Alliapoulos JC, Salusky IB, Hall T. Comparison of continuous cycling peritoneal dialysis with continuous ambulatory peritoneal dialysis in children. J Pediatr. 1984;105:721-5.

103. Rodríguez-Carmona A, Fontán MP, Falcón TG, Rivera CF, Valdés F. A comparative analysis on the incidence of peritonitis and exit-site infection in CAPD and automated peritoneal dialysis. Perit Dial Int. 1999;19:253-8.

104. Yishak A, Bernardini J, Fried L, Piraino B. The outcome of peritonitis in patients on automated peritoneal dialysis. Adv Perit Dial. 2001;17:205-8.

105. Oo TN, Roberts TL, Collins AJ. A comparison of peritonitis rates from the United States Renal Data System database: CAPD versus continuous cycling peritoneal dialysis patients. Am J Kidney Dis. 2005:45:372-80.

106. Davenport A. Peritonitis remains the major clinical complication of peritoneal dialysis: the London, UK, peritonitis audit 2002-2003. Perit Dial Int. 2009;29:297-302.
107. Nessim SJ, Bargman JM, Austin PC, Nisenbaum R, Jassal SV. Predictors of peritonitis in patients on peritoneal dialysis: results of a large, prospective Canadian database. Clin J Am Soc Nephrol. 2009:4:1195-200.

108. Mizuno M, Ito $Y$, Tanaka A, Suzuki $Y$, Hiramatsu $H$, Watanabe $M$, et al. Peritonitis is still an important factor for withdrawal from peritoneal dialysis therapy in the Tokai area of Japan. Clin Exp Nephrol. 2011;15:727-37.

109. Nishina M, Yanagi H, Kakuta T, Endoh M, Fulagawa M, Takagi A. A 10-year retrospective cohort study on the risk factors for peritoneal dialysis-related peritonitis: a single-center study at Tokai University Hospital. Clin Exp Nephrol. 2014;18:649-54

110. Losso RL, Minhoto GR, Riella MC. Sleep disorders in patients with end-stage renal disease undergoing dialysis: comparison between hemodialysis, continuous ambulatory peritoneal dialysis and automated peritoneal dialysis. Int Urol Nephrol. 2015;47:369-75.

\section{Submit your next manuscript to BioMed Central and we will help you at every step:}

- We accept pre-submission inquiries

- Our selector tool helps you to find the most relevant journal

- We provide round the clock customer support

- Convenient online submission

- Thorough peer review

- Inclusion in PubMed and all major indexing services

- Maximum visibility for your research

Submit your manuscript at www.biomedcentral.com/submit
) Biomed Central 